\section{Interacton of Benzimidazole and Nickel in Delaying the Senescence of Detached Rice Leaves *}

\author{
D. Mishra and B. SAmal
}

Laboratory of Plant Biochemistry and Enzymology, Department of Botany, Utkal University, Bhubaneswar-4, Orissa, India

(Z. Naturforsch. 26 b, 1377 [1971] ; received August 30, 1971)

Benzimidazole delays the senescence of detached leaves ${ }^{1-4}$. Nickel ions have also a preservative effect on the green pigment of detached leaves ${ }^{5-7}$. The effect of nickel in regulating senescence has not yet been adequately studied. Since both benzimidazole and Nickel chloride delay the senescence of detached leaves, a study was undertaken to measure the drifts in chlorophyll, protein, RNA and ribonuclease activity of leaves treated with these compounds during senescence.

Healthy and uniform leaves (ca. $5 \mathrm{~cm}$ length) of rice (Oryza sativa variety IR-8) were floated on $30 \mathrm{ml}$ test solutions in $10 \mathrm{~cm}$ petridishes. The test solutions were: Water (control), Benzimidazole $\left(10^{-3} \mathrm{M}\right)$, Nickel chloride $\left(10^{-3} \mathrm{M}\right)$ and the combination of benzimidazole and Nickel chloride at a final concentration of $10^{-3} \mathrm{M}$. To prevent contamination, chloramphenicol $(20 \mu \mathrm{g})$ and penicillin (120 units) were added to each of the petridishes. The leaves were floated on the test solutions for 120 hours in complete darkness at room temperature $\left(30^{\circ} \mathrm{C}\right)$, after which the samples were analysed for chlorophyll ${ }^{8}$, protein ${ }^{9}, \mathrm{RNA}^{\mathbf{1 0}}$ and ribonuclease ${ }^{11}$ activity. All the values are expressed as percent of the initial value, i. e. in terms of the contents present in the leaves before floatation. The experiment was repeated thrice and the values presented in Table I are the mean of three separate experiments.

Preliminary experiments established that more than $50 \%$ of the leaves showed visible sign of senescence within 120 hours of detachment. Hence the effect of these chemicals on the retention of chlorophyll, protein and RNA was measured at 120 hours after treatment. Benzimidazole reduced the loss of chlorophyll, protein and RNA (Table I).

* Paper No. 2 of the Plant Biochemistry and Enzymology Laboratory, Department of Botany, Utkal University, Bhubaneswar-4, India.

Requests for reprints should be sent to Dr. D. Mishra, Department of Botany, Utkal University, Bhubaneswar-4, Orissa, India.

1 C. Person, D. J. Samborski, and F. R. Forsyth, Nature [London] 180, 1294 [1957].

2 D. Mishra and B. Misra, Z. Pflanzenphysiol. 58, 207 [1968].

3 D. Mishra, Naturwissenschaften 53, 483 [1966].

4 D. Mishra and E. R. Waygood, Canad. J. Biochem. 46, 167 [1968].

\begin{tabular}{lcccc}
\hline Treatment & $\begin{array}{c}\text { Chloro- } \\
\text { phyll }\end{array}$ & $\begin{array}{l}\text { Pro- } \\
\text { tein }\end{array}$ & RNA & $\begin{array}{c}\text { Ribo- } \\
\text { nuclease } \\
\text { activity }\end{array}$ \\
\hline Water (Control) & $42 \mathrm{a}$ & $62 \mathrm{a}$ & $74 \mathrm{a}$ & 171 \\
Benzimidazole & 98 & 91 & $112 \mathrm{a}$ & 148 \\
Nickel chloride & 103 & 96 & $89 \mathrm{a}$ & 134 \\
Benzimidazole + & 104 & 99 & 100 & 153 \\
$\quad$ Nickel chloride & & & & \\
\hline
\end{tabular}

Table I. Effect of Treatments on the Changes in the Levels of Chlorophyll, Protein, RNA and in the activity of Ribonuclease at 120 hours after treatment. The values are expres. sed as percentage of the initial value. Mean of three experi ments. a Significantly different from the initial value $P=0.05$.

There was no loss of chlorophyll with Nickel chloride treatment but however, there was a very slight loss (4\%) in the protein content. RNA content increased $12 \%$ by benzimidazole but decreased $11 \%$ by Nickel chloride. In combination, benzimidazole and Nickel chloride was the best in the retention of chlorophyll, protein and RNA. Ribonuclease activity increased with detachment. This increase was the greatest in the leaves floated on water and the least with Nickel chloride treatment.

The results suggest that the breakdown of chlorophyll, protein and RNA typical of senescing leaves can be considerably arrested by treatment with benzimidazole and Nickel chloride separately or in combination. In this investigation there was an increase in RNA content over the initial value by benzimidazole treatment presumably due to increased turnover of RNA. The maximum senescence inhibition by Nickel chloride and benzimidazole + Nickel chloride observed in this study is striking. Inhibition of net chlorophyll, protein and RNA loss was however complete with benzimidazole + Nickel chloride. To the knowledge of the authors this is the first report on the effect of benzimidazole in combination with Nickel in completely inhibiting the senescence of rice leaves.

We are indebted to Prof. Dr. B. PADHI for providing necessary facilities to carry out this investigation. Acknowledgment is made to a grant from the University Grants Commission.

5 D. WANG, P. K. IsAAC, and E. R. WAYGOOD, Nature [London] 182, 268 [1958].

6 D. WANG and E. R. WAYGOoD, Canad. J. Bot. 37, 743 [1959].

7 W. R. Bushnell, Canad. J. Bot. 44, 1485 [1966].

8 D. I. Arnon, Plant Physiol. 24, 1 [1949].

9 A. G. Gornall, C. S. Bardwill, and M. M. David, J. biol. Chemistry 177, 751 [1949].

10 R. Markham, in: Modern Methods of Plant Analysis Vol. IV, Ed. K. Peach and M. V. Tracey, p. 246.

11 G. BAgI and G. L. FArkas, Phytochem. 6, 161 [1967]. 